\title{
The Role of Price and Promotion in Creating Brand Equity
}

\author{
Mehvish Umer* and Sohnia Salman**
}

\begin{abstract}
The purpose of this study is to ascertain the influence of price and promotion on brand equity, which eventually leads to the determination of consumer's preference for a particular brand. This research aims to add value to the current field by testing this relationship under the influence of three other mediating dimensions including the brand image, brand loyalty and quality of the product. In order to test the proposed model, the Structural Equation Modeling technique was used in this study. Within this realm, the CFA and path analysis were used to assess the validity and reliability of the latent constructs. The results of the research revealed that the price and promotion of a particular product have a statistically significant relationship with its brand equity. The results also seem to reject the mediating effect of brand image, perceived quality and brand loyalty between price and brand equity. The relationship of promotion, however, does allow for mediation by the perceived quality of a brand, but rejects the other two hypotheses. A number of researchers in Pakistan have previously conducted research on brand equity, albeit using different predictors in different industries. It must be noted that this proposed model of price and promotion, and its effects on the brand equity has not been thoroughly tested in the Pakistani context. Hence, this study proves to be a preliminary basis for further research on the linkages between price, promotion actions and brand equity.
\end{abstract}

Keywords: Perceived quality, brand image, brand equity, price and promotion.

JEL classification: L10, L20, M19, M31.

\section{Introduction}

In today's era of rapid globalization, branding has become an imperative part of successful and distinguished business practice. Branding is omnipotent in all different types of industries. It occupies a unique position in business at both national and international levels. What

\footnotetext{
* Assistant Professor, Lahore School of Economics, Lahore, Pakistan.

** Assistant Professor, Lahore School of Economics, Lahore, Pakistan.
} 
is also quite intriguing being that brands can be bought, sold, rented and borrowed (Majerova \& Kliestik, 2015). They are an essential component of a business - one that expresses the product in the form of a name, term, sign, symbol, design or logo, and hence, creates a strong and stable link of communication with the consumers (Misankova \& Chlebikova, 2013). A brand is a distinguished form of product information which incorporates how the consumers react to different marketing activities that are performed on the particular brand (Keller et al., 2011).

Since the early 1980s, extensive research has been conducted, specifically focusing on brand equity measurement (Erdem, Swait \& Valenzuela., 2006; Kamakura \& Gary, 1993). Other than this, there have also been a number of other studies, particularity emphasizing on brand value estimation (Ailawadi, Lehmann \& Neslin, 2003; Simon \& Sullivan, 1993). According to Keller (1993), brand equity is defined as "the differential effect of brand knowledge on consumer response to marketing of the brand." In Keller's (1993) research, this concept is particularly specified by the dissimilarities that exist between responses of consumers, when the marketing of branded / unbranded products is in question. His findings reveal that a more favorable response is given by consumers to brands with high brand equity, as compared to brands which possess low equity. In this regard, Farquhar (1989), p.24 "Brand equity is the "added value" with which a brand endows product; this added value can be viewed from the perspective of the firm, the trade, or the consumer".

The concept of brand equity holds critical importance for many organizations, as it has now become a priority for successful product marketing, and also aids the firms in developing a significant identity in the market (Aaker, 1991). The marketing strategies applied in order to strengthen the brand equity of a particular product are very useful, as they create value for the product's customers (Kim \& Damhorst, 2010). The brand equity of a particular brand, as a factor, is developed as a result of consumers' perceptions about the brand, and as a result, it symbolizes the position of the product in the minds of the consumers. In the empirical world where markets exist, we come in contact with different types of products on a daily basis. Due to the advent of different modes of advertisement, some brands are familiar to us, while others are not; therefore, launching a new brand can either lead to a product's and subsequently, a business's success, or failure. According to Cass and Grace (2003), branding helps in reducing the research cost, perceived risk, and the signal quality of the product for the consumers. Moreover, as we build upon this concept, it is noteworthy that, Aaker (1991, p.65) suggested that, 
"the set of brand assets and brand liability is related to the brand and its symbol, sign and brand name, and it also takes role of increasing or decreasing the values that a product or service offer to corporations or customers." He also proposed that brand assets are an amalgamation of brand loyalty, brand association, perceived quality, brand awareness and other properties. Other researchers (Heding, Knudtzen \& Bjerre, 2015) also classified brand awareness, brand image, perceived quality and brand loyalty, as a part of the brand equity realm (Shin, Kim, Lim \& Kim, 2014).

The importance of brand equity, in the field of marketing, cannot be overemphasized, as it is advantageous on multiple facets. A brand's strong equity will satiate the customers' wish to spend on top quality products. It will also encourage product documentation. Moreover, positive brand equity aids the performance of promotion interaction that is part of a firm's marketing strategy. From a retailer's point of view, strong brand equity will translate into a collaborative effort by the retailers as they will tend to work together and provide support to the business. Other than this, there will be a versatility of clients when pricing the discount rates. Lastly, a brand's positive equity will help make the clients' demand for the particular product, inelastic in nature, i.e., they would be willing to purchase the same or perhaps even more, despite the increase in price (Pitta \& Katsanis, 1995; Simon \& Sullivan, 1993; Yoo, Donthu \& Lee, 2000).

This research aims to explore whether price and promotion play a pivotal role in increasing brand equity. This paper has also attempted to explain the relationship between price and the promotion mix, and the growth of brand equity. A number of researchers (Aqeel et al., 2017; Shahzad, 2017) have conducted research on the concept of brand equity, using different predictors in different industries. The main contribution of this paper to the current research is an attempt to fill in the existing gaps in literature. This is undertaken by testing the impact of price and promotion on the brand equity, primarily by using three mediators in the context of Pakistani businesses. Moreover, it must be recognized that this research provides a basis for further research on the linkage between the different deciding factors which include the price, promotion actions, brand equity.

Section two of this paper gives a comprehensive review of the literature, along with the proposed hypothesis regarding price, promotion, brand image, perceived quality, brand equity, brand loyalty. Going further, section three presents the methodology used to conduct this research. Section four provides the background of the data sources, followed by the 
descriptive analysis and explanation of the research findings of this study. Finally, section five comprises of the discussion and conclusions drawn from the research conducted for the purpose of this study.

\section{Theory and Hypotheses}

This research aims to explore whether price and promotion play a critical role in increasing brand equity. Moreover, this paper also attempts to explain the relationship between price and promotion mix, and the growth of brand equity. The following section highlights the importance of these variables, and the hypotheses have been developed based on the reviewed literature, using references from past and future directions.

Brand equity is considered as an added value feature in the market that is targeted by a brand. It can either take the form of a product or a service (Ghantous \& Jaolis, 2012). The purpose of brand equity is to improve the brand loyalty, by taking into account the customer's feedback (Tan, Devinaga \& Hishamuddin, 2012). Brand association, brand awareness, perceived quality, brand image and brand loyalty are the basic drivers of brand equity (Aaker, 1991). Nam, Ekinci and Whyatt (2011) presented in their study the influence created by brand loyalty on brand equity, along with the facilitating effect of brand satisfaction in the hospitality sector, specifically focusing on the branch level which includes restaurants and hotels. It is thus stated that the major components of brand equity, in this case where the argument is narrowed down to the case of restaurants and hotels, includes the physical quality, brand identification, the conduct of the staff, ideal self-image and the ideal life style of the targeted customers. According to Atilgan et al. (2005), the brand equity can be measured in two ways, that is to say that it can either be finance centric or consumer centric. O'Loughlin and Szmigin (2007) suggest that the staff conduct, and physical quality are the two factors that can be used to measure effective management and administration for restaurant and hotel businesses. These two factors are directly involved in satiating the practical, on ground needs of the customers, while they are present in the premises of the hotel or restaurant. The paper explains the concept of brand equity in terms of assets and liabilities that are connected with the name, icon and value of the services of the brand (Pouromid \& Iranzadeh, 2012). The quality of the administration, or in other words, the administration quality can be measured by using five different factors. These include the accurate responsiveness, compassion, dependability, substance and certification of the brand in question (Parasuraman, Zeithaml \& Berry, 1988). Brands usually make their identities in the business sector, and 
different customers try to link themselves with these particular brands, due to which these brands eventually develop the ability to expend their brand and its presence in the market. When the shoppers expend the service or utility of their preferred brands, they are, at the same time, identifying their unique social personas from all other available social personalities that they can choose to identify with. The brands that possess a secured brand personality in their respective market tend to develop esteem and value in the eyes of the shoppers (Long \& Shiffman, 2000). A company can get access to high profits as its brand equity increases over time. Brand loyalty, brand image and brand awareness are then combined to form brand equity, which greatly influences the brand awareness of a particular brand

\subsection{Price}

Price is considered as the value or cost consumers need to pay in exchange for product or service. It is considered as the ultimate value of a consumer's ability and willingness to pay for a certain brand (Rajh, 2005). Usually, brands which have the highest price points attached to them are considered better, or more superior, because there is a positive relation between brand image and price. This perceptive relationship ultimately increases the brand equity of a particular brand. According to Yoo et al. (2000), the price of a product is considered an effective tool which can be used to differentiate one product or brand from another. Although price has a positive relationship with quality, it must be noted that it has an inverse relationship with brand loyalty. This is so because usually, the high price point does not reflect the product's quality, but it shows that a lot of money is going to the industrial sector. As a result, it affects the brand loyalty attached to it (Cretu \& Brodie, 2007; Michell, King \& Reast, 2001). On the contrary, according to a study, price reveals the satisfaction level for the brand, and thus this leads to an increase in the brand loyalty (Van et al., 2005). Therefore, the following hypotheses were proposed.

Hypothesis 1: Price is positively related to brand Image.

Hypothesis 2: Price positively affects perception of product quality.

Hypothesis 3: Price positively affects brand loyalty.

\subsection{Promotion}

Promotion is a marketing strategy that is used to communicate the targeted image of the product and its underlying message to the targeted 
consumer market. All the possible tools that aid in the brand's image building efforts are used including the communication mix. Brand loyalty and brand image carry a positive relationship with promotion (Al-Dmour, Zu'bi \& Kakeesh, 2013). Milgrom and Roberts (1986) also presented the idea that product quality can be easily and effectively judged through the brand promotion. Yoo et al. (2000) put forward a concept, which basically states that product promotion helps the companies to ensure a positive brand image in the eyes of the consumers. Hence, this leads to the belief that brand promotion is an easy way to increase brand equity, as it provides a platform to develop and create a positive brand image in the minds of the people.

The marketers in today's digital age come face to face with new prospects, opportunities and challenges every single day. By utilizing the electronic media sources (e.g. mobile phones SMS and MMS, social media marketing, display advertising, tablets, digital billboards, internet marketing, search engines optimization etc.) marketers promote different products and services to a wider customer base on a national as well as a global level. The basic aim of digital promotion is to provide a platform for customers to interact with brands on a direct basis, and as a result, attract more customers as there are no defined boundaries in the digital world. The effectiveness of digital promotion has a significant impact on the sales of products as proposed by Yasmin, Tasneem and Fatema (2015). Mangold and Faulds (2009) support the effective use of digital promotion as it improves and builds up on a brand's loyalty, it is more cost effective, creates a better brand image, and improves customer satisfaction. According to Van Riel, Pahud de Mortanges and Streukens (2005), there is a positive influence of promotion on the perceived quality, and brand loyalty towards a particular brand. As per the above discussion, the following hypotheses were proposed.

Hypothesis 4: Promotion is positively related to brand Image.

Hypothesis 5: Promotion is positively related to quality perception.

Hypothesis 6: Promotion is positively related to brand loyalty.

\subsection{Brand Image}

Brand image can be perceived as a set of relations that are formed in a special way, in the minds of the consumers, so that they leave a cognitive impact especially in the form of future recollection of the particular brand in 
question. It also refers to the perception about the product, that may or may not be real and accurate (Keller, 1993). Brand image also provides the customer with the required information that he or she may need in order to make a decision to buy the product. The concept is also important because it differentiates one product from another, and creates uniqueness between them as well. It develops an optimistic approach for the consumer as well (Hsu, Oh \& Assaf, 2012). According to a study, the relationship between brand image and brand equity holds lesser importance, as compared to any of the other determinants (Atilgan, Aksoy \& Akinci, 2005). Al-Dmour et al. (2013) explains brand image as a reflection of a brand's position in the minds of the customers. The research also explains that the brand image can be considered as one the measures of brand equity, and thus, it studies how the marketing mix affects the brand image. These efforts can contribute towards making the relationship between brand equity and marketing mix a little more clear and relevant. Consequently, another research revealed that a positive relationship existed between the brand image and marketing mix (Shabbir \& Rehman, 2013). The following hypothesis proposes that brand image mediates the link between price and brand equity. Similarly, the hypothesis 7a postulates that brand image can act as a mediator between promotion and brand equity.

Hypothesis 7: The brand image mediates the relationship between price and brand equity.

Hypothesis 7a: The brand image mediates the relationship between promotion and brand equity.

\subsection{Perceived Quality}

"Perceived Quality is considered as the judgment of the consumer about a product's overall excellence or superiority" (Zeithaml, 1988). AlDmour et al. (2013) explain that perceived quality is an essential component of brand equity. Moreover, the concept also holds a positive relationship with the marketing mix. According to Bamert and Wehrli (2005), service quality and product quality are both required to measure the perceived quality of a brand, and it must be noteworthy that they are both dependent on the consumer's perception. If the things that determine the quality of the product in the consumer's mind are taken into account, and as a next step, their perceptions are managed effectively; this information can prove to be a key factor which impacts the perceived quality of a brand. The results (Bamert and Wehrli (2005), revealed that service quality has an important relationship with both, brand image and 
brand loyalty, whereas, product quality indicates no significant relationship with either the brand image or the brand loyalty. Hence, the results proved that not just brand equity but service quality is also an important factor with which customers measure the brand equity. Aghaei, Vahedi, Kahreh and Pirooz (2014), in their research, determine whether brand equity and marketing mix are positively related.

Hypothesis 8: The perceived quality mediates the relationship between price and brand equity.

Hypothesis 8a: The perceived quality mediates the relationship between promotion and brand equity.

\subsection{Brand Loyalty}

Bianchi, Pike \& Lings (2014), explained brand loyalty as the repetitive purchases of the same brand. The attachment of the customer with the brand is known as brand loyalty (Aaker, 1991). Al-Dmour et al. (2013) describes brand loyalty as a special feeling that is felt by the customer, especially for a particular brand. Nenycz and Romaniuk (2011) deemed the measurement of brand loyalty to be very important as the results of this measurement ultimately reveal that the number of people who buy that brand upsurge its brand equity. As customers are very important for the brand's productivity, it is also equally critical to maintain the purchase intent of the customers for a particular brand. There are certain decisions that customers make, which leads them to repurchase a brand, which shows evidence of their loyalty towards their preferred brands. According to Nam et al. (2011), there is a positive relationship between brand loyalty and brand equity, including the intervention effect, which is related to the brand satisfaction. It is usually believed that getting a new customer on board is much more expensive and costly then retaining an old one. The maintenance of customers is usually assumed to be linked with their leap into a higher income bracket, or a decline in their expenses. As a result, every service or product provider is given a vote of sympathy, as it is actually the customer's situation and not the marketer's competency that is inconsistent (Woisetschläger, Lentz \& Evanschitzky, 2011). In a study by Pan, Sheng and Xie (2012), it is explained that customer loyalty is very important for an organization, as it helps in developing a strong base of customers. An organization can create a strong bond with its customers by creating, nurturing and protecting their confidence in them. As per the above discussion, the following hypotheses were proposed. 
Hypothesis 9: The brand Loyalty mediates the relationship between price and brand equity.

Hypothesis 9a: The brand Loyalty mediates the relationship between promotion and brand equity.

\section{Theoretical Framework}

Figure 1 and Figure 2 demonstrate the relationship of each construct with brand equity.

Figure 1: Framework demonstrating the relationship between Price and Brand Equity

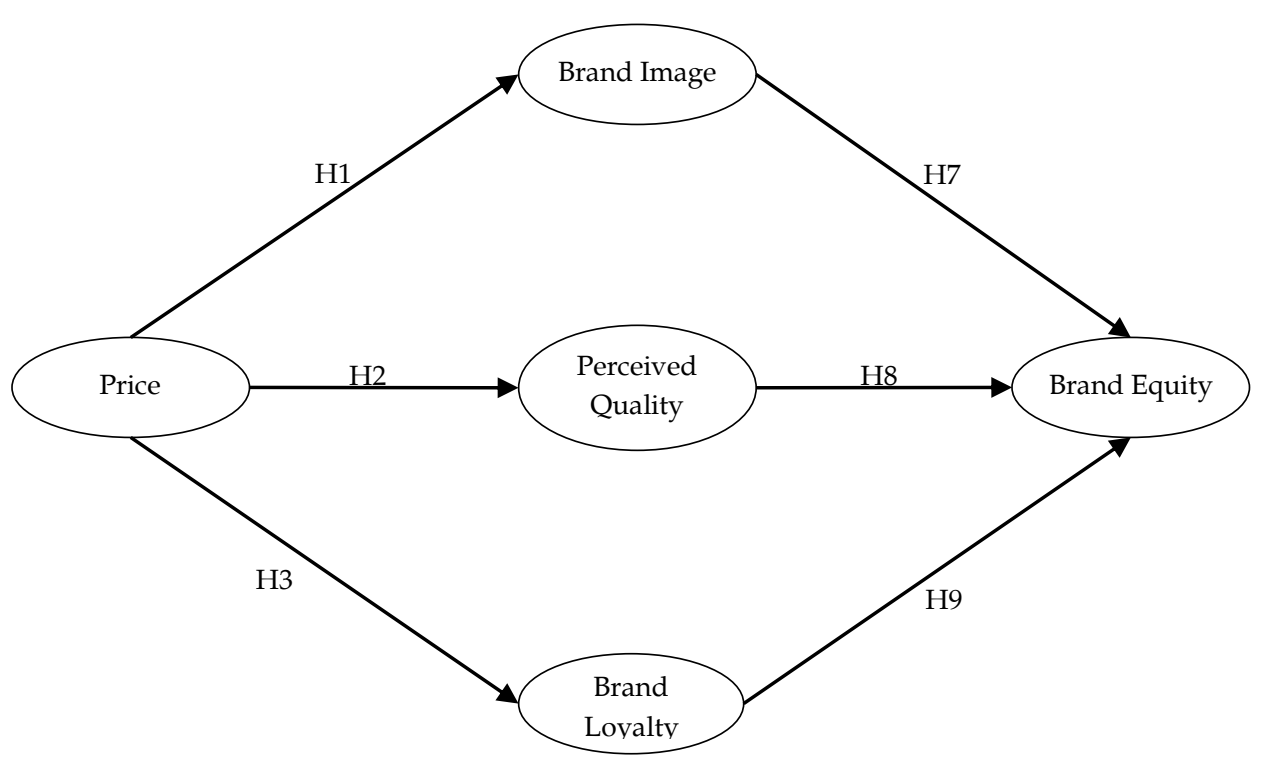




\section{Figure 2: Framework demonstrating the relationship between Promotion and Brand Equity}

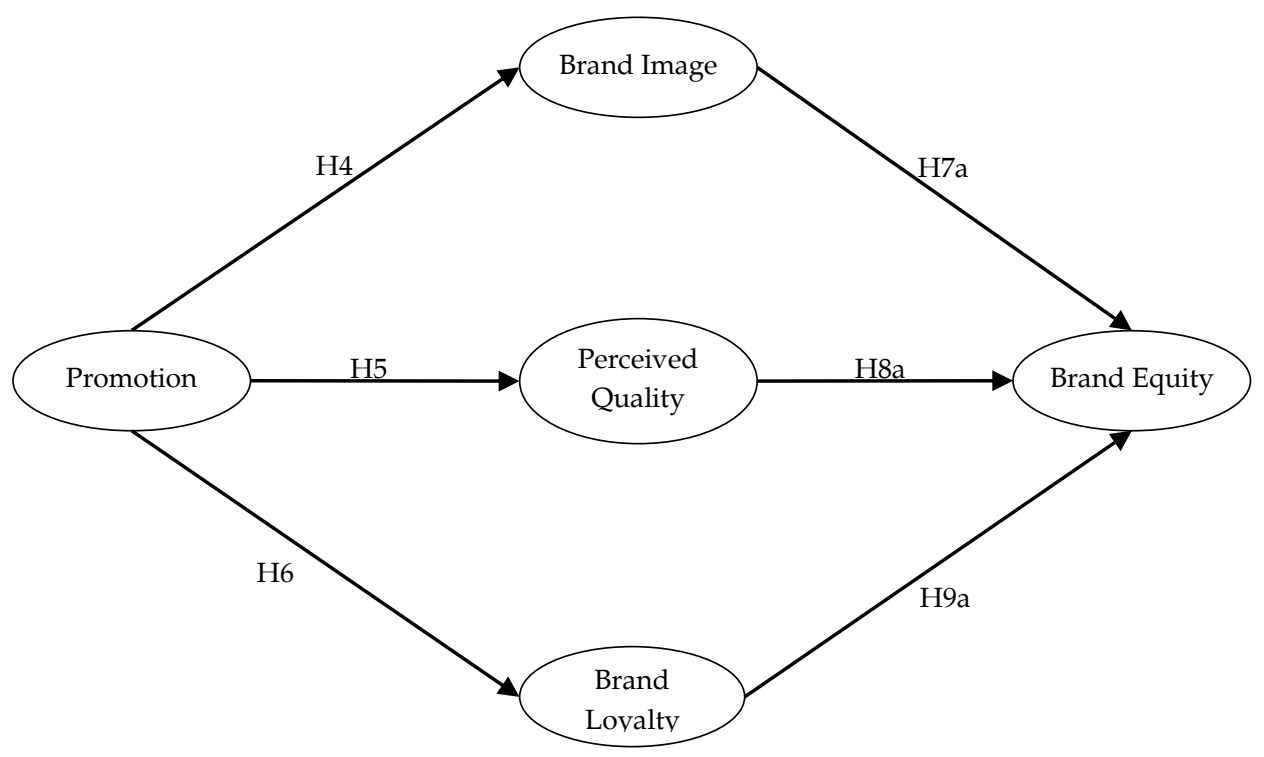

\section{Methodology}

The following section discusses the data collection and analysis techniques used to test the proposed hypotheses of this study. It recapitulates the methods adopted to collect the data, and the expertise used to test it.

\subsection{Sample Size}

A questionnaire was distributed among the general public in the urban areas of Lahore. A sample size of 215 was selected through convenience sampling. Sample size is the key component required in order to use the structural equation modelling. In order to procure the sample size, two principals have to be taken into consideration. For SEM, the large sample model is used and the sample that comprise of more than 200 samples, unites together and is considered to be large. Moreover, the complexity of the structural model when selecting the sample size also needs to be taken into considered. The ratio between the parameter number, and the sample size should be at least 1:10, as a ratio less than 1:5 does not give any significant results (Kline, 1998, p. 343). 


\subsection{Data Collection}

The research has been conducted using SPSS 20 and AMOS 18 in order to observe the impact of price and promotion, on brand equity. For this purpose, a questionnaire was designed consisting of questions regarding the socio-demographic factors. These factors were selected on the basis of the literature reviewed. Therefore, sample of items was generated and measured on a scale ranging from 1 to 7 , where 7 refers to the respondent strongly agreeing to the statement, and 1 referring to the respondent to strongly disagreeing to the statement.

\section{Results and Discussion}

\subsection{Descriptive Analysis}

The primary source of the data for this study is the 215 questionnaires that were filled in by the general public in Lahore's urban residential housing societies. Respondents belonged to different ages, education, gender and localities. The questionnaire included the sociodemographic information of all the respondents.

A total of 260 respondents participated in the survey, while due to incomplete responses, 45 of these questionnaires were excluded from the study. The table shows that $63.2 \%$ of respondents belonged to the age group of 20-25 years. The number of male respondents was $36 \%$, while the female respondents amounted to $64 \%$ of the total sample. Moreover, $66 \%$ of the respondents were students of bachelors' level of education. The highest number of respondents fell into an income bracket of PKR 10,00025,000 , respectively.

Structural Equation Modelling The Confirmatory factor analysis (CFA) is used for the purpose of analyzing the data and also verifying whether the questionnaire items are reliable and valid or not. For the purpose of this study, the benchmark for the factor loading test was 0.5 (Chang \& Chen, 2008). The reliability of the study was tested using the Cronbach alpha and composite reliability measures. The cut point for the Cronbach alpha was set at 0.6, as proposed by Slater (1995) and Taber (2018), whereas the benchmark for composite reliability was kept at 0.6, as proposed by Singh at al. (2011). In order to fulfill the set requirements, items with a factor loading of less than 0.5 were removed from the model fit. The analysis was carried out on the basis of 6 measures, and these included the Price, Promotion, Brand loyalty, Brand Equity, Perceived 
Quality and the Brand Image. Several items were discarded from all the variables, and the model fit was completed for this particular study. Table 1 shows the factor loading of the items, which is above 0.5. Initially, the questionnaire comprised of 36 items for all the variables, but due to less than 0.5 factor loading, 9 items were discarded and the measurement was further narrowed down to the remaining items.

Table 1: Reliability Analysis

\begin{tabular}{|c|c|c|c|c|}
\hline Variables & Items & Factor Loadings & $\begin{array}{c}\text { Cronbach } \\
\text { Alpha }\end{array}$ & $\begin{array}{l}\text { Composite } \\
\text { Reliability }\end{array}$ \\
\hline \multirow[t]{3}{*}{ Price } & Q6 & 0.615 & 0.641 & 0.842 \\
\hline & Q7 & 0.700 & & \\
\hline & Q8 & 0.514 & & \\
\hline \multirow[t]{2}{*}{ Brand Equity } & Q1 & 0.950 & 0.784 & 0.807 \\
\hline & Q2 & 0.679 & & \\
\hline \multirow[t]{4}{*}{ Promotions } & Q10 & 0.740 & 0.802 & 0.801 \\
\hline & Q11 & 0.650 & & \\
\hline & Q12 & 0.702 & & \\
\hline & Q13 & 0.741 & & \\
\hline \multirow[t]{2}{*}{ Brand image } & Q15 & 0.785 & 0.788 & 0.788 \\
\hline & Q16 & 0.821 & & \\
\hline \multirow{3}{*}{$\begin{array}{l}\text { Perceived } \\
\text { Quality }\end{array}$} & Q27 & 0.674 & 0.808 & 0.814 \\
\hline & Q28 & 0.787 & & \\
\hline & Q29 & 0.846 & & \\
\hline \multirow[t]{3}{*}{ Brand Loyalty } & Q32 & 0.821 & 0.694 & 0.788 \\
\hline & Q33 & 0.682 & & \\
\hline & Q35 & 0.543 & & \\
\hline
\end{tabular}

The value of the Average Variance Extracted (AVE) is used for testing the reliability and validity, with standardized solutions in CFA (Hult, Ketchen \& Slater, 2004). For the validity of this study, both the convergent validity and discriminant were evaluated. The Convergent validity was tested, using the average variance extracted (AVE) method with a benchmark of 0.4, as suggested by Verhoef, Franses and Hoekstra (2002), whereas the discriminant was tested by comparing AVE to the squared correlations of all constructs as suggested by Fornell and Larcker (2011).

Table 2 indicates the AVE values for price, brand equity, promotion, brand image, perceived qualityand brand loyalty. The AVE values for all the 6 constructs fell in the acceptable range hence, the convergent validity also showed evidence of validity. It also assured that reliable items have been used in order to measure the constructs. Hence, all constructs in this study were reliable and valid. 
Table 2: Reliability and Validity

\begin{tabular}{lccc}
\hline Variable & AVE & Convergent Validity & Composite Reliability \\
\hline Price & 0.792 & Holds & Holds \\
Brand Equity & 0.744 & Holds & Holds \\
Promotion & 0.827 & Holds & Holds \\
Brand Image & 0.817 & Holds & Holds \\
Perceived Quality & 0.846 & Holds & Holds \\
Brand Loyalty & 0.743 & Holds & Holds \\
\hline
\end{tabular}

The measurement of the model fits were assessed by making use of several indices. By examining the past literature, the benchmark criterion for each value was determined. The Maximum Likelihood method was employed in the initial estimation in order to test the proposed model. By examining the past literature, the benchmark criterion for each value was determined, and used in the current research as shown in Table 3.

\section{Table 3: Benchmark Criterion}

\begin{tabular}{|c|c|c|}
\hline Indexes & Criterion & References \\
\hline CMIN/d.f. & Less than 5 & (Sharma, Young \& Wilkinson, 2006) \\
\hline RMSEA & Less than 0.11 & (Smillie, Jackson \& Dalgleish, 2006) \\
\hline Goodness-of-Fit Index (GFI) & Greater than 0.6 & (Rafferty \& Restubog, 2011) \\
\hline AGFI & Greater than 0.8 & (Nsairi \& Khadraoui, 2013) \\
\hline $\begin{array}{l}\text { Non-Normed Fit Index } \\
\text { (NNFI or TLI) }\end{array}$ & Greater than 0.6 & $\begin{array}{l}\text { (Donaldson, Everitt, Newton, } \\
\text { Steele, Sherriff \& Bower, 2008) }\end{array}$ \\
\hline Comparative Fit Index (CFI) & Greater than 0.6 & $\begin{array}{l}\text { (Donaldson, Everitt, Newton, } \\
\text { Steele, Sherriff \& Bower, 2008) }\end{array}$ \\
\hline Incremental Fit Index (IFI) & Greater than 0.6 & (Abaied \& Rudolph, 2010) \\
\hline Reliability and Validity & Greater than 0.5 & $\begin{array}{l}\text { (Hair, Hollingsworth, Randolph \& } \\
\text { Chong, 2017) }\end{array}$ \\
\hline
\end{tabular}

The model fit results seemed to be satisfactory and there was no uni-dimensionality noticed in the revelations $(\mathrm{CMIN} / \mathrm{df}=1.887, \mathrm{RMSEA}=$ 0.065, GFI $=0.90, \quad$ AGFI $=0.854, \quad \mathrm{CFI}=0.919, \mathrm{NFI}=0.846, \mathrm{TLI}=0.894$, $\mathrm{IFI}=0.921)$.

Results revealed that the relationship between price, and brand image was found to be significant ( $p$ value $<0.05$ ). Price is a very important component in building the commercial value of a particular brand, especially in terms of its market position and perception with customers and competitors. In branding literature, generally, the symbolic meanings of brands are more often highlighted (Biel, 1992; Hamiln \& Wilson, 2004). Some researchers believe that brands provide customers with the foundation to express themselves (Anselmsson, Vestman Bondesson \& 
Johansson, 2014; Temporal \& Lee, 2000). This idea has been supported by empirical work in this field, and hence proposes that the brand image, indeed is a very vital feature which impacts the responses of customers in a variety of categories (Kandampully \& Suhartanto, 2000). Beyond its direct relationship with the sales and profits of a company, price has a significant impact on the brand itself, as higher prices lead to a premium brand image (Yoo, Donthu \& Lee, 2000). On the other hand, lower price points serve to undercut the competition, and sometimes tend to spoil the brand image as well.

According to the results of the study, a significant positive relationship between price and perceived quality ( $p$ value $<0.05$ ) shows the importance of this very relationship. These findings are also consistent with the previous findings (Bei \& Chiao, 2001; Nisbett \& Ross, 1980). That is to say that the price of a particular brand is a very critical aspect, which the customers of specific brands enjoy. Price tends to enhance the value and meaning of a product, along with distinguishing its brand from its competitors. Buyers usually assume that there is a positive relationship between the price and the perceived quality, as they compare the price of a specific product with that of the other alternatives in the market (CollinsDodd \& Lindley, 2003). The higher priced brand is perceived, by the customers, to be a better, premium quality product, as compared to a lower price alternative product (Rao \& Monroe, 1989; Zeithaml, 1988).

The price and brand loyalty demonstrate a strong positive relationship with each other and are found to be significant ( $p$ value $<0.05$ ). Loyalty is defined as an essential variable of segmentation, and a crucial element of long term brand viability (Delgado \& Luis, 2001). The Purchase quantity decision, and brand choice decision are two decisions that lead to the ultimate brand purchase decision (Krishnamurthi \& Raj, 1991). The traditional view point suggests that loyal customers of a specific brand will always be price insensitive. The relationship between loyalty and price sensitivity is inseparable, i.e., there is a direct relationship between these two variables. Regardless of the price, the loyal customers will choose their preferred brand more often because of strong its brand attributes. Non loyal customers will be expected to behave in the opposite manner when it comes to making choices in decision making (Chaudhuri, 1999; Gounaris \& Stathakopoulos, 2004).

According to the results, promotion and brand image showed a significant and positive relationship with each other ( $p$ value $<0.05$ ). As advertising has drastically increased over the years, in today's era, it is 
presumed that brand image is a deliberate asset for organizations. In order to break this image, companies should consider different promotional strategies so as to attract and establish the brand image in the consumer's subconscious mind (Villarejo \& Sanchez, 2005; Wu, Yeh \& Hsiao, 2011). This is critical because strategic business asset such as brands have gained importance over the course of the past years. According to Aaker (1996), the high value brands aid the companies in terms of the competitive advantage that they offer. Several past researches also support the relationship between promotion and brand image (Montaner \& Pina, 2011; Villarejo \& Sanchez, 2005).

Promotion and perceived quality also showed a positive relationship with each other. Brands attain recognition through marketing communication and advertising, as these are their core promotional mechanisms in the consumer market (Villarejo \& Sanchez, 2005). Promotion is one of the strategic external indicators of product quality (Dew \& Huebner, 1994). The relationship between promotional activities and quality has not only been observed in perceived quality of the brands, but also proved to be significant in the purchase decision in terms of actively increasing the value of product (Nandan, 2005).

Promotion and brand loyalty showed a highly significant ( $\mathrm{p}$ - value $<0.05$ ) positive relationship which primarily indicates that the promotional and communicational activities play a vital role in creating brand loyalty along with positive brand equity. This relationship is also justified by different studies which were conducted previously, and revealed similar results (Casaló, Flavián \& Guinalíu, 2010; Gedenk \& Neslin, 2000).

The relationship between brand equity and the perceived quality was found to be statistically significant, and this revelation is supported by other studies that were conducted previously (Aaker, 2009; Severi \& Ling, 2013; Yoo, Donthu \& Lee, 2000). Perceived quality plays a mediating role between the price, promotion and brand equity of a particular brand (Chi, Yeh \& Yang, 2009).

The consumers bonding with the brands that they like to consume can be defined effectively as loyalty, happiness or love, and is primarily dependent on the amount of affection displayed towards a specific brand (Albert et al., 2008; Albert \& Merunka, 2013; Batra, Ahuvia \& Bagozzi, 2012; Carroll \& Ahuvia, 2006; Kanga, A., 2015; Keh et al., 2007; Shimp \& Madden, 1988; Thomson et al., 2005; Whang et al., 2004). 
The relationship between brand image and brand loyalty, along with its affiliation with brand equity was found to be insignificant ( $\mathrm{p}$-value $>$.05). These results basically proved that brand image and brand loyalty cannot act as mediators in the proposed model.

Table 4: Hypotheses Results

\begin{tabular}{llccc}
\hline & & $\begin{array}{c}\text { Standardized } \\
\text { Estimates }\end{array}$ & Hypothesis & Significance \\
\hline Price & $\rightarrow$ Brand Image & 0.373 & H1 Accepted & $* *$ \\
Price & $\rightarrow$ Perceived Quality & 0.862 & H2 Accepted & $* * *$ \\
Price & $\rightarrow$ Brand Loyalty & 0.427 & H3 Accepted & $* * *$ \\
Promotion & $\rightarrow$ Brand Image & 0.216 & H4 Accepted & $* * *$ \\
Promotion & $\rightarrow$ Perceived Quality & 0.234 & H5 Accepted & $* *$ \\
Promotion & $\rightarrow$ Brand Loyalty & 0.170 & H6 Accepted & $* * *$ \\
Brand Image & $\rightarrow$ Brand Equity & 0.105 & H7 Rejected & Insignificant \\
Perceived Quality & $\rightarrow$ Brand Equity & 0.240 & H8 Accepted & $* *$ \\
Brand Loyalty & $\rightarrow$ Brand Equity & 0.149 & H9 Rejected & Insignificant \\
\hline
\end{tabular}

${ }^{* * *} \mathrm{p}<0.00,{ }^{* *} \mathrm{p}<0.05$

\section{Mediation Results}

The mediation results (table 5) were based on Baron \& Kenny (1986) methodology. The results of the mediation hypothesis show that there is no mediation, as the direct route shows a significant relationship between promotion and brand image, while the indirect route shows an insignificant relationship between brand image and brand equity. The hypothesis which proposed the route from promotion to perceived quality to brand equity is, thus, partially accepted, as it shows significant results in both routes. There is no mediation as the direct route between price and brand equity is significant, while the indirect routes show insignificant results. 


\section{Table 5: Mediation Analysis}

\begin{tabular}{lcccc}
\hline Variables & $\begin{array}{c}\text { Direct Effect } \\
\text { Without } \\
\text { mediator } \\
\text { (p- value) }\end{array}$ & $\begin{array}{c}\text { Direct Effect } \\
\text { with mediator } \\
\text { (p- value) }\end{array}$ & $\begin{array}{c}\text { Indirect } \\
\text { Effect with } \\
\text { mediator } \\
\text { (p- value) }\end{array}$ & $\begin{array}{c}\text { Final } \\
\text { Results }\end{array}$ \\
\hline $\begin{array}{l}\text { Promotion to } \\
\text { Brand Image to }\end{array}$ & 0.013 & 0.021 & 0.310 & No mediation \\
$\begin{array}{l}\text { Brand Equity } \\
\text { Promotion to }\end{array}$ & 0.013 & 0.012 & 0.041 & $\begin{array}{c}\text { Partial } \\
\text { Perceived quality } \\
\text { to Brand Equity }\end{array}$ \\
$\begin{array}{l}\text { Promotion to } \\
\text { Brand loyalty to }\end{array}$ & 0.013 & 0.015 & 0.129 & $\begin{array}{c}\text { No } \\
\text { Brand Equity }\end{array}$ \\
$\begin{array}{l}\text { Price to Brand } \\
\text { Image to Brand }\end{array}$ & 0.021 & 0.211 & 0.143 & No mediation \\
$\begin{array}{l}\text { Equity } \\
\text { Price to }\end{array}$ & & & & No mediation \\
$\begin{array}{l}\text { Perceived quality } \\
\text { to Brand Equity } \\
\text { Price to Brand } \\
\text { loyalty to Brand } \\
\text { Equity }\end{array}$ & 0.021 & 0.073 & 0.112 & No mediation \\
\hline$* * *$ p $<0.00, * *$ p $<0.05$ & 0.021 & 0.104 & 0.165 & \\
\hline
\end{tabular}

\section{Conclusions}

The findings of the study suggest that price and promotion have a significant impact on brand equity. It is therefore concluded that brand image has no mediation effect in terms of the promotion to brand equity. This was also identified from the direct effects, as there was a significant relationship, whereas on the other hand, the indirect effect confirms a negative relationship. Results revealed that there is a significant relationship between the paths of promotion, starting from the perceived quality to brand equity. Moreover, brand loyalty is found not to be a mediator between promotion and brand equity, since the direct route shows a significant relationship between the two, however, the indirect route shows an insignificant relationship.

This study offers many managerial suggestions and points to ponder for the service oriented businesses and corporations. Brand equity serves as a valuable tool for evaluating the marketing activities of companies. This particular evaluation will assist its audience in getting 
valuable feedback from the customers and in return benefit in terms of the problems that they identify in relation to the services that they provide and their advertising and marketing endeavors. This systematic approach provides a pathway for the managers to establish and exercise mechanisms of brand equity, and consequently gauge the effectiveness of their branding strategies (Ishaq, Hussain, Asim \& Cheema, 2014).

In order to strengthen the brand image and loyalty, the brand image plays through the various marketing activities that are undertaken to get the brand to resonate in the minds of the consumers. Due to strong brand awareness, the managers are forced to increase their service quality and consumer satisfaction, which as a result, increases their positive brand reputation, brand loyalty and overall profitability of the organization.

It must be noted that the research experienced a few limitations. This research does not include all the variables present in the marketing mix. The other variables, including the place, product and placement, if considered, will certainly offer a greater insight into the topic. One of the most significant flaws in this research is that it emphasizes only on one sector of Pakistan's service industry, i.e. the restaurant and hotel industry. Also, future studies can further test the relationship between brand equity and brand love through sequential mediation analysis of this model. 


\section{References}

Aaker, D. A. (1991). Managing Brand Equity: Capitalizing on the Value of a Brand Name. New York: Free Press.

Aaker, D. A. (1996). Building Strong Brands. New York: Free Press.

Aaker, D. A. (1996). Measuring brand equity across products and markets. California Management Review, 38(3).102-120

Aaker, D. A. (2009). Managing brand equity. New York, United States: John Wiley \& Sons.

Abaied, J. L., \& Rudolph, K. D. (2010). Mothers as a resource in times of stress: Interactive contributions of socialization of coping and stress to youth psychopathology. Journal of Abnormal Child Psychology, 38(2), 273-289.

Aghaei, M., Vahedi, E., Kahreh, M. S., \& Pirooz, M. (2014). An examination of the relationship between services marketing mix and brand equity dimensions. Procedia-Social and Behavioral Sciences, 109, 865-869.

Ailawadi, K. L., Lehmann, D. R., \& Neslin, S. A. (2003). Revenue premium as an outcome measure of brand equity. Journal of Marketing, 67(4), 1-17.

Al-Dmour, H., Zu'bi, M. F., \& Kakeesh, D. (2013). The Effect of Services Marketing Mix Elements on Customer-Based Brand Equity: An Empirical Study on Mobile Telecom Service Recipients in Jordan. International Journal of Business and Management, 8(11), p13.

Anselmsson, J., Vestman Bondesson, N., \& Johansson, U. (2014). Brand image and customers' willingness to pay a price premium for food brands. Journal of Product E Brand Management, 23(2), 90-102.

Aqeel, Z., Hanif, M. I., \& Malik, M. S. (2017). Impact of co-branding and brand personality on brand equity: A study of telecom sector in Pakistan. Journal of Business and Retail Management Research, 12(1), 86-93

Atilgan, E., Aksoy, S., \& Akinci, S. (2005). Determinants of the brand equity: a verification approach in the beverage industry in Turkey. Marketing Intelligence E Planning, 23(3), 237-248. 
Bamert, T., \& Wehrli, H. P. (2005). Service quality as an important dimension of brand equity in Swiss services industries. Managing Service Quality: An International Journal, 15(2), 132-141.

Baron R. M. Kenny D.A., 1986. The moderator-mediator variable distinction in social psychological research: conceptual, strategic, and statistical considerations. Journal of Personality and Social Psychology. 51(6), 1173-1182.

Batra, R., Ahuvia, A., \& Bagozzi, R. P. (2012). Brand love. Journal of Marketing, 76(2), 1-16.

Bei, L. T., \& Chiao, Y. C. (2001). An integrated model for the effects of perceived product, perceived service quality, and perceived price fairness on consumer satisfaction and loyalty. Journal of Consumer Satisfaction, Dissatisfaction and Complaining Behavior, 14, 125-140.

Bianchi, C., Pike, S., \& Lings, I. (2014). Investigating attitudes towards three South American destinations in an emerging long haul market using a model of consumer-based brand equity (CBBE). Tourism Management, 42, 215-223.

Biel, A. L. (1992). How brand image drives brand equity. Journal of Advertising Research, 32(6), 6-12.

Casaló, L. V., Flavián, C., \& Guinalíu, M. (2010). Relationship quality, community promotion and brand loyalty in virtual communities: Evidence from free software communities. International Journal of Information Management, 30(4), 357-367.

Cass, O. A. \& Grace, D. (2003). An Exploratory Perspective of Service Brand Associations. Journal of Services Marketing, 17 (5), 452-475.

Chang, H. H., \& Chen, S. W. (2008). The impact of customer interface quality, satisfaction and switching costs on e-loyalty: Internet experience as a moderator. Computers in Human Behavior, 24(6), 2927-2944.

Chaudhuri, A. (1999). Does brand loyalty mediate brand equity outcomes? Journal of Marketing Theory and Practice, 7(2), 136-146

Chi, H. K., Yeh, H. R., \& Yang, Y. T. (2009). The impact of brand awareness on consumer purchase intention: The mediating effect of perceived 
quality and brand loyalty. The Journal of International Management Studies, 4(1), 135-144.

Collins-Dodd, C., \& Lindley, T. (2003). Store brands and retail differentiation: The influence of store image and store brand attitude on store own brand perceptions. Journal of Retailing and Consumer Services, 10(6), 345-352.

Cretu, A. E., \& Brodie, R. J. (2007). The influence of brand image and company reputation where manufacturers market to small firms: A customer value perspective. Industrial Marketing Management, 36(2), 230-240.

Dew, T., \& Huebner, E. S. (1994). Adolescents' perceived quality of life: An exploratory investigation. Journal of School Psychology, 32(2), 185-199.

Donaldson, A. N., Everitt, B., Newton, T., Steele, J., Sherriff, M., \& Bower, E. (2008). The effects of social class and dental attendance on oral health. Journal of Dental Research, 87(1), 60-64.

Erdem, T., Swait, J., \& Valenzuela, A. (2006). Brands as signals: A crosscountry validation study. Journal of Marketing, 70(1), 34-49.

Farquhar, P. H. (1989). Managing brand equity. Marketing research, 1(3) 24-33.

Fornell, C., \& Larcker, D. F. (1981). Structural equation models with unobservable variables and measurement error: Algebra and statistics.

Gedenk, K., \& Neslin, S. A. (2000). The role of retail promotion in determining future brand loyalty: Its effect on purchase event feedback. Journal of Retailing, 75(4), 433-459.

Ghantous, N., \& Jaolis, F. (2012). Conceptualizing franchisee-based brand equity-A framework of the sources and outcomes of the brand's added value for franchisees. International Business Research, 6(2), p112.

Gounaris, S., \& Stathakopoulos, V. (2004). Antecedents and consequences of brand loyalty: An empirical study. The Journal of Brand Management, 11(4), 283-306. 
Hair, J., Hollingsworth, C. L., Randolph, A. B., \& Chong, A. Y. L. (2017). An updated and expanded assessment of PLS-SEM in information systems research. Industrial Management E Data Systems, 117(3), 442-458.

Hamiln, R. P., \& Wilson, T. (2004). The impact of cause branding on consumer reactions to products: does product/cause'fit'really matter? Journal of Marketing Management, 20(7-8), 663-681.

Heding, T., Knudtzen, C. F., \& Bjerre, M. (2015). Brand management: Research, theory and practice (pp. 314). London: Routledge

Hsu, C. H., Oh, H., \& Assaf, A. G. (2012). A customer-based brand equity model for upscale hotels. Journal of Travel Research, 51(1), 81-93.

Hult, G. T. M., Ketchen, D. J., \& Slater, S. F. (2004). Information processing, knowledge development, and strategic supply chain performance. Academy of Management Journal, 47(2), 241-253.

Ishaq, M. I., Hussain, N., Asim, A. I., \& Cheema, L. J. (2014). Brand equity in the Pakistani hotel industry. Revista de Administração de Empresas, 54(3), 284-295.

Jensen, M. B., \& Klastrup, K. (2008). Towards a B2B customer-based brand equity model. Journal of Targeting, Measurement and Analysis for Marketing, 16(2), 122-128.

Kamakura, W. A., \& Gary J. R. (1993). Measuring Brand Value with Scanner Data. International Journal of Research in Marketing, 10 (3), 9-21.

Kandampully, J., \& Suhartanto, D. (2000). Customer loyalty in the hotel industry: the role of customer satisfaction and image. International Journal of Contemporary Hospitality Management, 12(6), 346-351.

Keller, K. L. (1993). Conceptualizing, Measuring, and Managing CustomerBased Brand Equity. Journal of Marketing, 57 (1), 1-22.

Keller, K. L., Parameswaran, M. G., \& Jacob, I. (2011). Strategic brand management: Building, measuring, and managing brand equity. India: Pearson Education. 
Kim, J., \& Damhorst, M. L. (2010). Effects of level of internet retailer's service quality on perceived apparel quality, perceived service quality, perceived value, satisfaction, and behavioral intentions toward an internet retailer. Clothing and Textiles Research Journal, 28(1), 56-73

Kline, R. B. (1998). Software review: Software programs for structural equation modeling: Amos, EQS, and LISREL. Journal of Psychoeducational Assessment, 16(4), 343-364.

Krishnamurthi, L., \& Raj, S. P. (1991). An empirical analysis of the relationship between brand loyalty and consumer price elasticity. Marketing Science, 10(2), 172-183.

Long, M. M., \& Schiffman, L. G. (2000). Consumption values and relationships: segmenting the market for frequency programs. Journal of Consumer Marketing, 17(3), 214-232.

Majerova, J., \& Kliestik, T. (2015). Brand valuation as an immanent component of brand value building and managing. Procedia Economics and Finance, 26, 546-552.

Mangold, W. G., \& Faulds, D. J. (2009). Social media: The new hybrid element of the promotion mix. Business Horizons, 52(4), 357-365.

Michell, P., King, J., \& Reast, J. (2001). Brand values related to industrial products. Industrial Marketing Management, 30(5), 415-425.

Milgrom, P., \& Roberts, J. (1986). “Price and Advertising Signals of Product Quality." Journal of Political Economy, 55 (8), 10-25

Misankova, M., \& Chlebikova, D. (2013). Possibilities for financing innovation activities in Slovak Republic. 9th International Scientific Conference on Financial Management of Firms and Financial Institutions, Financial Management of Firms and Financial Institutions (pp. 562-570). Ostrava, Czech Republic: Elsevier

Montaner, T., \& Pina, J. M. (2011). The effect of promotion type and benefit congruency on brand image. Journal of Applied Business Research (JABR), 24(3), 15-28 
Nam, J., Ekinci, Y., \& Whyatt, G. (2011). Brand equity, brand loyalty and consumer satisfaction. Annals of Tourism Research, 38(3), 1009-1030.

Nandan, S. (2005). An exploration of the brand identity-brand image linkage: A communications perspective. Journal of Brand Management, 12(4), 264-278.

Nenycz-Thiel, M., \& Romaniuk, J. (2011). The nature and incidence of private label rejection. Australasian Marketing Journal (AMJ), 19(2), 93-99.

Nisbett, R. E., \& Ross, L. (1980). Human inference: Strategies and shortcomings of social judgment. New York, United States: Prentice-Hall

Nsairi, Z. B., \& Khadraoui, M. (2013). Website satisfaction: determinants and consequences on website loyalty. International Business Research, 6(9), 77-92.

O'loughlin, D., \& Szmigin, I. (2007). Services branding: Revealing the rhetoric within retail banking. The Service Industries Journal, 27(4), 435-452.

Pan, Y., Sheng, S., \& Xie, F. T. (2012). Antecedents of customer loyalty: An empirical synthesis and reexamination. Journal of Retailing and Consumer Services, 19(1), 150-158.

Parasuraman, A., Zeithaml, V. A., \& Berry, L. L. (1988). Servqual: A multiple-item scale for measuring consumer perceptions of service quality. Journal of Retailing, 64(1), 12

Pitta, D.A. and L.P. Katsanis, 1995, "Understanding Brand Equity for Successful Brand Extension".Journal of Consumer Marketing, 12(4), 51-64.

Pouromid, B., \& Iranzadeh, S. (2012). The Evaluation of the Factors Affects on the Brand Equity of Pars Khazar Household Appliances Based on the Vision of Female Consumers. Middle-East Journal of Scientific Research, 12(8), 1050-1055.

Rafferty, A. E., \& Restubog, S. L. D. (2011). The influence of abusive supervisors on followers' organizational citizenship behaviours: The hidden costs of abusive supervision. British Journal of Management, 22(2), 270-285. 
Rajh, E. (2005). The effects of marketing mix elements on brand equity. Privredna kretanja i ekonomska politika, 15(102), 30-30.

Rao, A. R., \& Monroe, K. B. (1989). The effect of price, brand name, and store name on buyers' perceptions of product quality: An integrative review. Journal of Marketing Research, 26(3), 351-357.

Severi, E., \& Ling, K. C. (2013). The mediating effects of brand association, brand loyalty, brand image and perceived quality on brand equity. Asian Social Science, 9(3), 125

Shabbir, J., \& Rehman, K. U. (2013). Impact of Perceptual Dimensions and Behavioral dimension on brand equity in Pakistan. Information Management and Business Review, 5(7), 347.

Shahzad, K. (2017). Determinants of Brand Equity and Its Causes \& Consequences A Study of Automobiles Oil from Peshawar Region Pakistan. Economic Analysis, 45(3-4), 60-66.

Sharma, N., Young, L., \& Wilkinson, I. (2006). The commitment mix: Dimensions of commitment in international trading relationships in India. Journal of International Marketing, 14(3), 64-91.

Shin, N., Kim, H., Lim, S., \& Kim, C. (2014). The effect of brand equity on brand attitude and brand loyalty in exhibition. In SHS Web of Conferences (Vol. 12, p. 01018). EDP Sciences.

Shimp, T. A. (1997). Advertising, promotion, and supplemental aspects of integrated marketing communications. Orlando, FL: Harcourt Brace College

Simon, C.J. and M.W. Sullivan, 1993, "The Measurement and Determinants of Brand Equity: A Financial Approach". Marketing Science, 12(1), pp. 28-52.

Singh, A. S., Vik, F. N., Chinapaw, M. J., Uijtdewilligen, L., Verloigne, M., Fernández-Alvira, J. M., \& Brug, J. (2011). Test-retest reliability and construct validity of the ENERGY-child questionnaire on energy balance-related behaviors and their potential determinants: the ENERGY-project. International Journal of Behavioral Nutrition and Physical Activity, 8(1), 136. 
Slater, S. F. (1995). Issues in conducting marketing strategy research. Journal of Strategic Marketing, 3(4), 257-270.

Smillie, L. D., Jackson, C. J., \& Dalgleish, L. I. (2006). Conceptual distinctions among Carver and White's (1994) BAS scales: A reward-reactivity versus trait impulsivity perspective. Personality and Individual Differences, 40(5), 1039-1050.

Taber, K. S. (2018). The use of Cronbach's alpha when developing and reporting research instruments in science education. Research in Science Education, 48(6), 1273-1296.

Tan, T. M., Devinaga, R., \& Hishamuddin, I. (2012). The Common Challenges of Brand Equity Creation among Local Fast Food Brands in Malaysia. International Journal of Business and Management, 8(2), 96.

Temporal, P., \& Lee, K. C. (2000). Hi-tech hi-touch branding: creating brand power in the age of technology. New York, United States of America: John Wiley \& Sons

Van Riel, A. C. R., Pahud de Mortanges, C., \& Streukens, S. (2005). Marketing antecedents of industrial brand equity: An empirical investigation in specialty chemicals. Industrial Marketing Management, 34(8), 841-847.

Verhoef, P. C., Franses, P. H., \& Hoekstra, J. C. (2002). The effect of relational constructs on customer referrals and number of services purchased from a multiservice provider: does age of relationship matter? Journal of the Academy of Marketing Science, 30(3), 202-216.

Villarejo-Ramos, A. F., \& Sanchez-Franco, M. J. (2005). The impact of marketing communication and price promotion on brand equity. Journal of Brand Management, 12(6), 431-444.

Woisetschläger, D. M., Lentz, P., \& Evanschitzky, H. (2011). How habits, social ties, and economic switching barriers affect customer loyalty in contractual service settings. Journal of Business Research, 64(8), 800-808. 
Wu, P. C., Yeh, G. Y. Y., \& Hsiao, C. R. (2011). The effect of store image and service quality on brand image and purchase intention for private label brands. Australasian Marketing Journal (AMJ), 19(1), 30-39.

Yasmin, A., Tasneem, S., \& Fatema, K. (2015). Effectiveness of digital marketing in the challenging age: An empirical study. International Journal of Management Science and Business Administration, 1(5), 69-80.

Yoo, B., Donthu, N., \& Lee, S. (2000). An examination of selected marketing mix elements and brand equity. Journal of the Academy of Marketing Science, 28(2), 195-211.

Zeithaml, V. A. (1988). Consumer perceptions of price, quality, and value: a means-end model and synthesis of evidence. Journal of Marketing, 52(3) 2-22. 


\section{Appendix}

\section{Table 1: Construct Definitions}

\begin{tabular}{|c|c|c|}
\hline Constructs & Operational Definition & References \\
\hline Price & $\begin{array}{l}\text { Price is the value at which the restaurant service } \\
\text { is consumed (Al-Dmour et al. (2013)). The } \\
\text { research will measure the importance a customer } \\
\text { gives to brand equity on the basis of his } \\
\text { willingness to pay. Four items have been } \\
\text { extracted from the literature. }\end{array}$ & Yoo et al. (2000) \\
\hline Promotion & $\begin{array}{l}\text { Promotion is the act of transforming the message } \\
\text { of the product strategy to the target market, } \\
\text { using all the available tools- including } \\
\text { communication mix- by the marketer (Al-Dmour } \\
\text { et al. (2013)). } 6 \text { items were selected to measure } \\
\text { promotion. }\end{array}$ & Yoo et al. (2000) \\
\hline $\begin{array}{l}\text { Brand } \\
\text { image }\end{array}$ & $\begin{array}{l}\text { Brand image can be defined as the impression } \\
\text { made up of a product or brand by a customer } \\
\text { (Keller (2008)). } 7 \text { factors selected from the } \\
\text { previous study. }\end{array}$ & Kim \& Kim (2005) \\
\hline $\begin{array}{l}\text { Brand } \\
\text { loyalty }\end{array}$ & $\begin{array}{l}\text { The study measures brand loyalty as a } \\
\text { customer's preference for a certain brand over } \\
\text { other brands, Aaker (1991). This variable is } \\
\text { measured using } 10 \text { items from the study. }\end{array}$ & Kim \& Kim (2005) \\
\hline $\begin{array}{l}\text { Perceived } \\
\text { quality }\end{array}$ & $\begin{array}{l}\text { Perceived quality is the consumer's perception } \\
\text { about a product's overall quality and } \\
\text { supremacy, Zeithaml (1988). This variable is } \\
\text { measured using } 10 \text { items from the study. }\end{array}$ & Kim \& Kim (2005) \\
\hline $\begin{array}{l}\text { Brand } \\
\text { Equity }\end{array}$ & $\begin{array}{l}\text { Aaker (1991), defines brand equity as "a set of } \\
\text { brand assets and liabilities connected to a band, } \\
\text { name and its symbol that add to or subtract from } \\
\text { the value provided by a product or service to a } \\
\text { firm". } 4 \text { items selected for measurement. }\end{array}$ & Yoo \& Donthu (1997) \\
\hline
\end{tabular}

